\title{
Pengembangan Bahan Ajar Berbasis Multimedia Pembelajaran Interaktif Model Borg And Gall Materi Listrik Dinamis Kelas X SMA Negeri 1 Marawola
}

\author{
Luhur Agus Utomo, Muslimin, Darsikin \\ Email: luhur.utomo93@gmail.com \\ Program Studi Pendidikan Fisika, Jurusan Pendidikan MIPA, Universitas Tadulako, \\ Jl. Soekarno Hatta KM. 9 Kampus Bumi Tadulako Tondo Palu - Sulawesi Tengah
}

\begin{abstract}
Penelitian ini bertujuan untuk menghasilkan multimedia pembelajaran interaktif materi Listrik Dinamis dan mengetahui kelayakan multimedia pembelajaran interaktif materi Listrik Dinamis. Jenis penelitian ini adalah penelitian dan pengembangan (research \& development) model Borg and Gall yang disederhanakan oleh puslitjaknov dengan melibatkan lima langkah yaitu: 1) analisis produk yang dikembangkan, 2) pengembangan produk, 3) validasi ahli dan revisi, 4) uji coba kelompok kecil dan revisi, 5) produk akhir. Hasil penelitian berupa multimedia pembelajaran interaktif materi Listrik Dinamis yang layak digunakan berdasarkan penilaian dari ahli materi dengan penilaian aspek pembelajaran 3,5, aspek Kurikulum 3,5, dan aspek isi materi 3,67 dengan kategori sangat baik, dan ahli media dengan penilaian aspek pewarnaan 3, aspek pemakaian kata dan bahasa 3, aspek tampilan layar 3, aspek perintah 3, dan aspek desain tampilan 3 dengan kategori baik. Uji coba kelompok kecil berjumlah 6 orang siswa dengan nilai rata-rata semua aspek 3,799 termasuk dalam kategori sangat baik. Sehingga secara keseluruhan multimedia pembelajaran interaktif yang dihasilkan mempunyai kualitas kelayakan sangat baik.
\end{abstract}

Kata Kunci : Listrik Dinamis, Multimedia Pembelajaran Interaktif.

\section{PENDAHULUAN}

Metode pembelajaran konvensional masih banyak diterapkan oleh guru di dalam kelas. Guru lebih banyak berperan sebagai informan bagi siswa. Materi-materi yang dirasa penting dicatatkan oleh guru di papan tulis. Siswa cenderung pasif dalam pembelajaran. Interaksi antara guru dengan siswa hampir tidak ada. Keadaan seperti ini membuat siswa merasa bosan dengan proses pembelajaran yang hanya didominasi oleh guru. Siswa kurang dapat menerima apalagi memahami materi pelajaran. Hal seperti itu juga terjadi di SMA Negeri 1 Marawola Kab. Sigi dan perlu dicarikan solusi.

Penggunaan multimedia pembelajaran interaktif di SMA Negeri 1 Marawola sampai saat ini belum pernah dilaksanakan, padahal faktor pendukung telah dimiliki yaitu tersedianya laboratorium komputer yang berisi 28 unit komputer yang siap digunakan.

Sebagai langkah awal perlu segera dilakukan pengembangan bahan ajar berbasis multimedia pembelajaran interaktif materi listrik dinamis, sehingga tercipta media pembelajaran berupa multimedia pembelajaran interaktif yang layak dan baik guna terciptanya pembelajaran yang interaktif, inspiratif, menyenangkan, kreatif, menantang dan memotivasi peserta didik.

Pertama yang harus dilakukan adalah menetapkan lebih dulu model pengembangan MPI yang akan digunakan sebagai acuan pengembangan. Pada pengembangan awal ini sangat cocok jika menggunakan pengembangan model Borg \& Gall, karena tujuan penelitian dan pengembangan menurut Borg \& Gall adalah untuk mengembangkan dan memvalidasi produk yang dikembangkan sesuai pernyataan Borg \& Gall $(1983: 772)^{[1]}$ yaitu " $R \& D$ is process used to develop and validate educational products". Selain itu sesuai pernyataan Borg dan Gall dalam Emzir $(2013: 271)^{[2]}$ yang menyarankan untuk membatasi penelitian dalam skala kecil, termasuk dimungkinkan membatasi langkah penelitian. Itulah sebabnya kenapa pengembangan model Borg \& Gall dipilih sebagai model pengembangan MPI ini. 


\section{METODE PENELITIAN}

Jenis penelitian ini adalah penelitian dan pengembangan atau Research and Development (R\&D) menurut Borg dan Gall dalam Puslitjaknov $(2008: 11)^{[3]}$ yang dapat dibuat lebih sederhana dengan melibatkan 5 langkah utama yaitu :

1. Melakukan analisis produk yang akan dikembangkan

2. Mengembangkan produk awal

3. Validasi ahli dan revisi

4. Ujicoba lapangan skala kecil dan revisi produk

5. Ujicoba lapangan skala besar dan produk akhir

Karena adanya keterbatasan waktu dan biaya, pada penelitian dan pengembangan yang akan dilaksanakan hanya sampai uji coba lapangan skala kecil dengan tujuan terciptanya bahan ajar berbasis multimedia interaktif yang baik dan dapat digunakan.

Subjek dalam penelitian ini adalah siswa kelas X SMA Negeri 1 Marawola. Subyek dalam penelitian ini berjumlah 6 siswa sebagai subyek uji coba kelompok kecil.

Dalam mendapatkan data penelitian, diadakan validasi terhadap program yang telah dirancang dan dibuat untuk menentukan kelayakan dan program tersebut, serta respon dari pengguna. Data diambil dari ahli materi, ahli media pembelajaran, dan dari siswa SMA/MA kelas $X$. Teknik pengumpulan data dalam penelitian ini adalah dengan menggunakan teknik angket/ instrumen. Teknik ini dipilih karena responden yaitu ahli materi, dosen ahli media, dan dari siswa yang dianggap memiliki pengetahuan dasar tentang Listrik Dinamis.

Dalam penelitian ini ada dua macam data yang dianalisis. Yang pertama data kualitatif yang berupa kritik dan saran dari yang dikemukakan oleh ahli media, ahli materi, dan pengguna pada saat pengumpulan data dan validasi program, dihimpun dan dirangkum sebagai pedoman untuk memperbaiki multimedia yang dikembangkan. Yang kedua data kuantitatif yang diperoleh dari hasil penilaian ahli materi, ahli media dan pengguna. Data kuantitatif ini dianalisis menggunakan statistik deskriptif kualitatif. Teknik analisis data menggunakan statistik deskriptif yang kemudian dikonversikan menjadi data kualitatif skala 5 menggunakan acuan konversi dari Sukardjo (dalam Saifudin, 2012) $)^{[4]}$ pada Tabel 1.

Tabel 1 Kriteria Penilaian Kelayakan MPI

\begin{tabular}{|c|c|c|}
\hline nilai & Kriteria & Rentang \\
\hline 5 & Sangat Baik & $X>X i+1,80$ Sbi \\
\hline 4 & Baik & $\begin{array}{c}\mathrm{Xi}+0,60 \mathrm{Sbi}<\mathrm{X} \leq \mathrm{Xi}+ \\
1,80 \mathrm{Sbi}\end{array}$ \\
\hline 3 & Cukup & $\begin{array}{c}\text { Xi }-0,60 \text { Sbi }<X \leq X i+ \\
0,60 \text { Sbi }\end{array}$ \\
\hline 2 & Kurang & $\begin{array}{c}\text { Xi }-1,80 \text { Sbi }<X \leq X i- \\
0,60 \text { Sbi }\end{array}$ \\
\hline 1 & Sangat Kurang & $X \leq X i-1,80$ Sbi \\
\hline
\end{tabular}

Keterangan:

$\mathrm{X} \mathrm{i}=$ Rerata ideal $=1 / 2$ (skor maks + skor $\mathrm{min}$ ) $\mathrm{Sbi}=$ Simpang baku ideal $=1 / 6$ (skor maks skor min) $\mathrm{X}=$ Skor aktual

\section{HASIL DAN PEMBAHASAN}

Pengembangan yang dihasilkan dalam penelitian ini yaitu berupa multimedia pembelajaran interaktif dengan materi yang ditampilkan secara berjenjang dan soal dalam uji kompetensi maupun evaluasi ditampilkan secara acak.

Dalam software multimedia pembelajaran interaktif ini berisi Sembilan halaman utama yaitu :

Halaman 1 : Tampilan awal program, berisi judul, form login, dan registrasi

Halaman 2 : Tampilan menu program, berisi menu untuk mengakses halaman

Halaman 3 : Berisi materi Besaranbesaran listrik

Halaman 4 : Berisi materi Rangkaian listrik sederhana (satu loop)

Halaman 5 : Berisi materi Identifikasi penerapan listrik AC dan DC dalam kehidupan sehari-hari

Halaman 6 : Berisi evaluasi dalam pembelajaran Listrik Dinamis

Halaman 7 : Berisi laporan hasil uji kompetensi dan evaluasi

Halaman 8 : Berisi Petunjuk menjalankan program

Halaman 9 : Berisi Standar kompetensi dan kompetensi dasar 
Tabel 2. Tampilan Multimedia Pembelajaran Interaktif Materi Listrik Dinamis

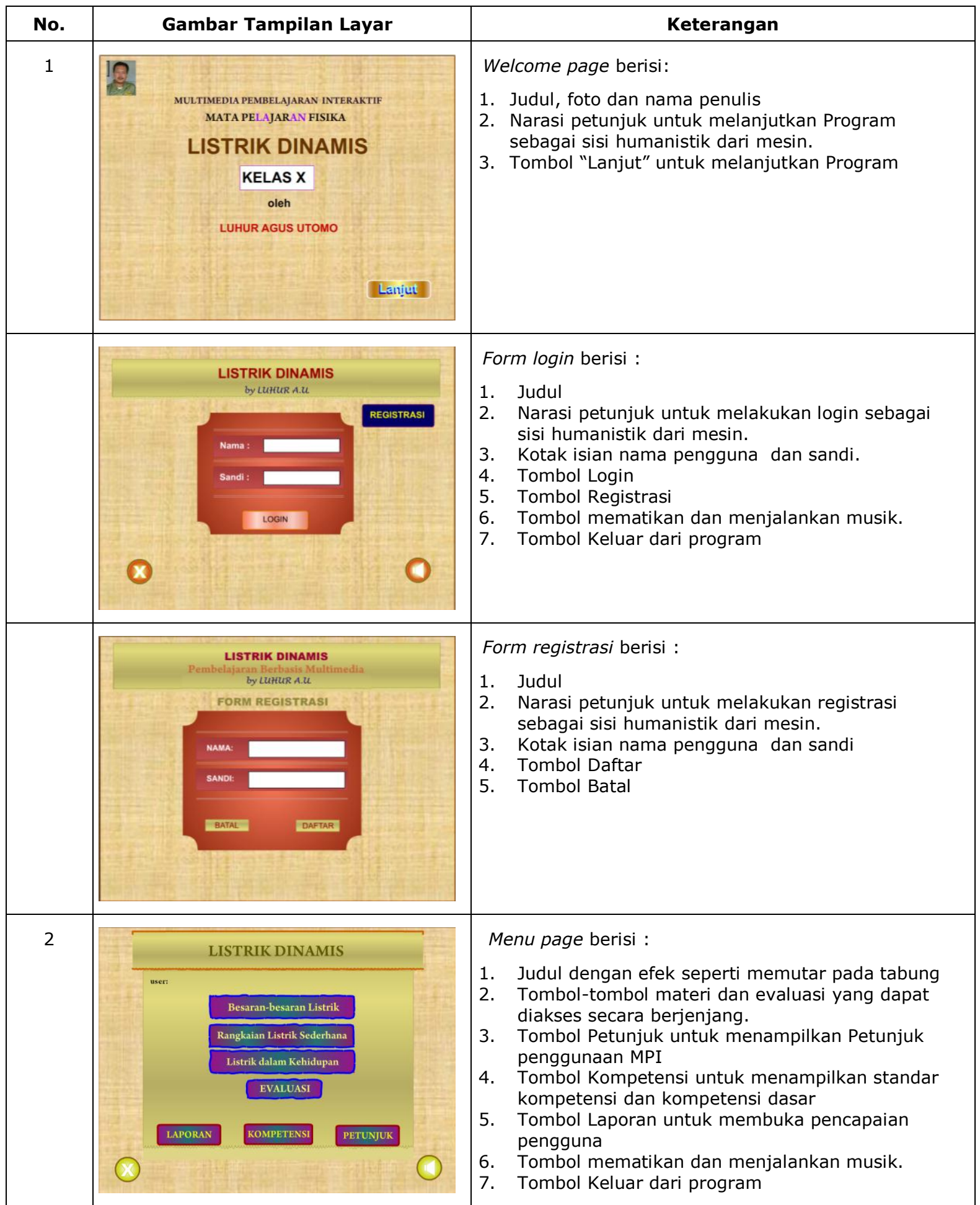




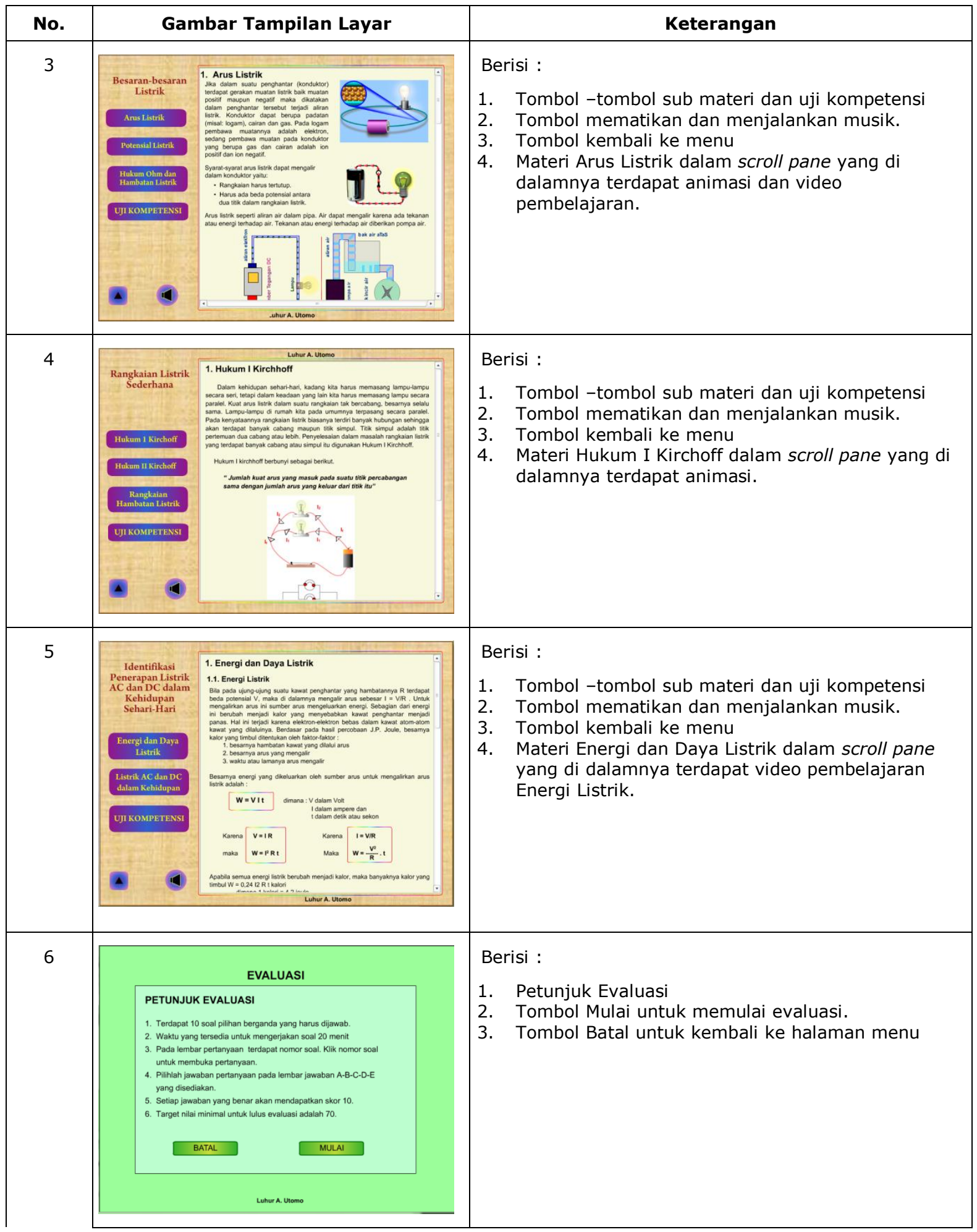




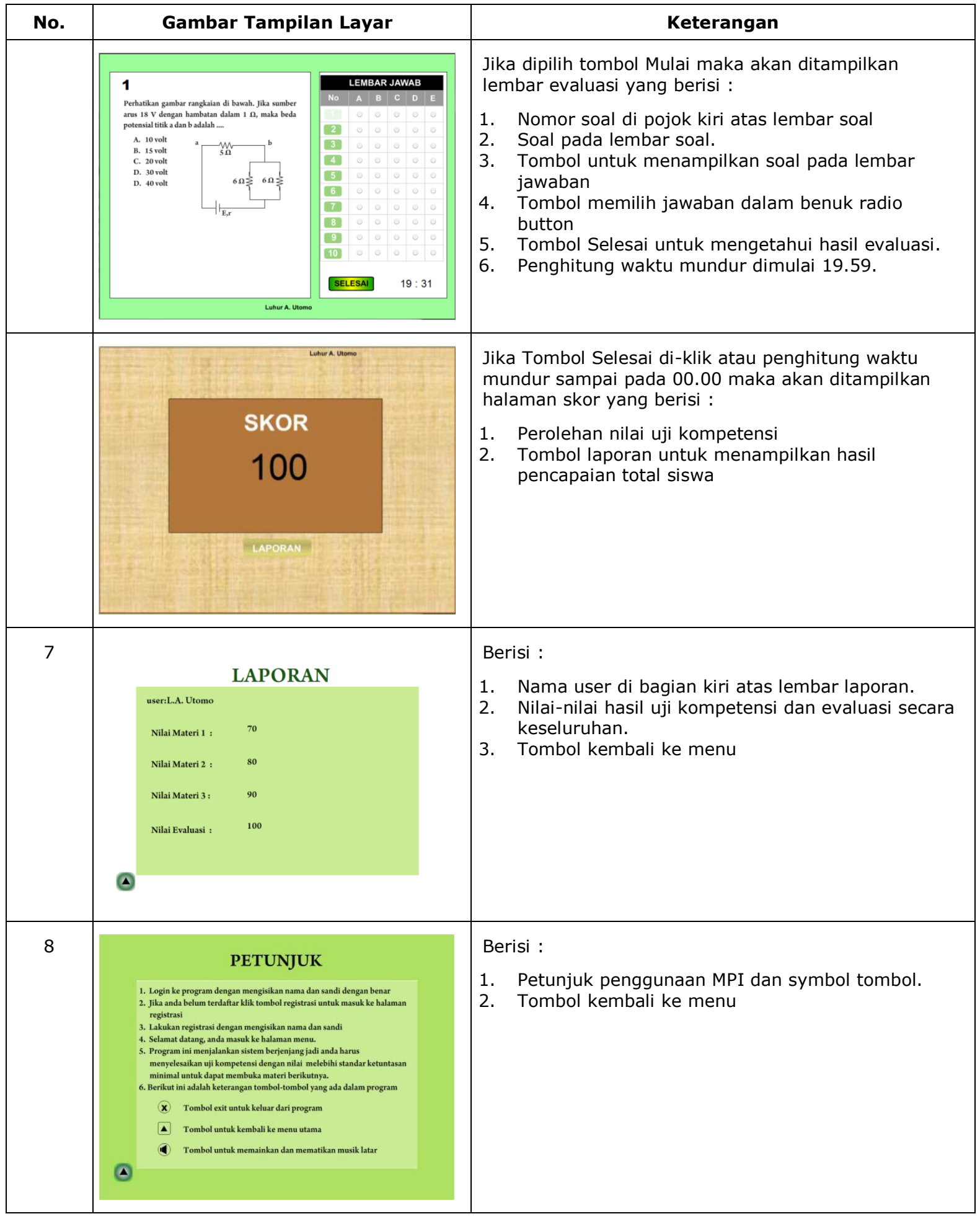




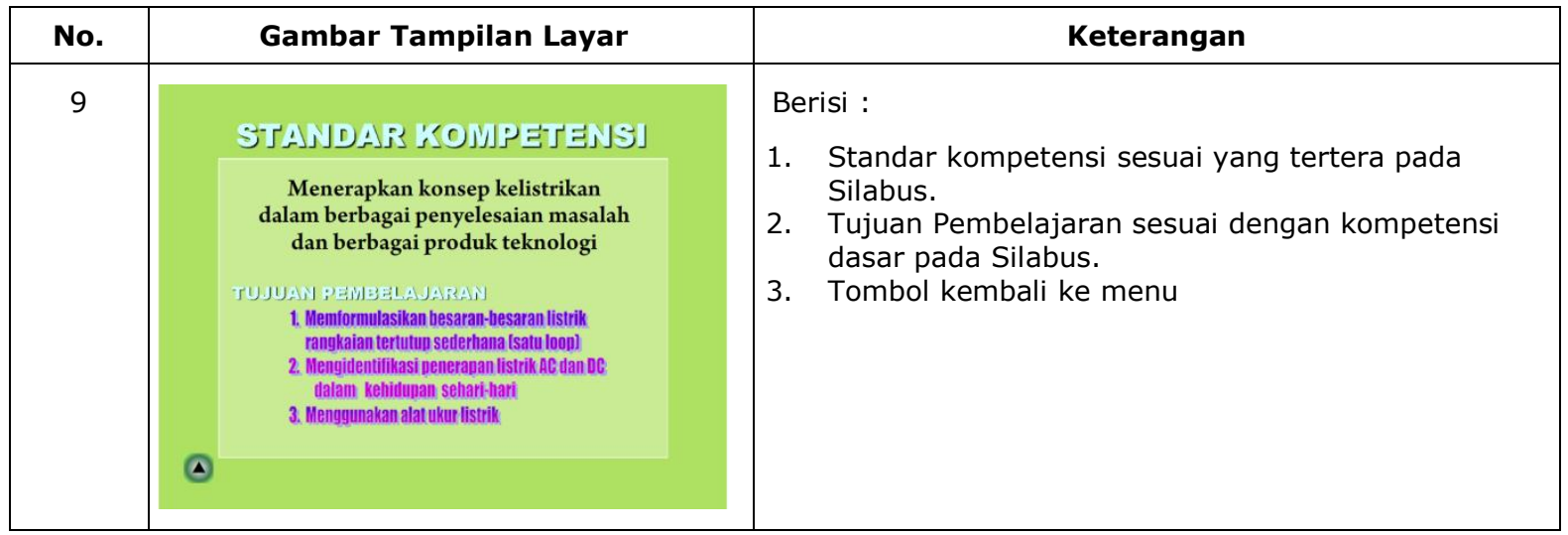

Hasil review ahli materi menunjukkan validitas multimedia pembelajaran interaktif memperoleh kualifikasi sangat baik (lihat Gambar 1). Hasil ini artinya multimedia pembelajaran interaktif pada aspek pembelajaran, kurikulum dan isi materi telah sesuai dan layak digunakan dalam pembelajaran. Revisi pada tahap ini adalah penyempurnaan kalimat, menambahkan persamaan untuk memperjelas materi, menambahkan contoh soal, dan mempertajam gambar yang kurang jelas.

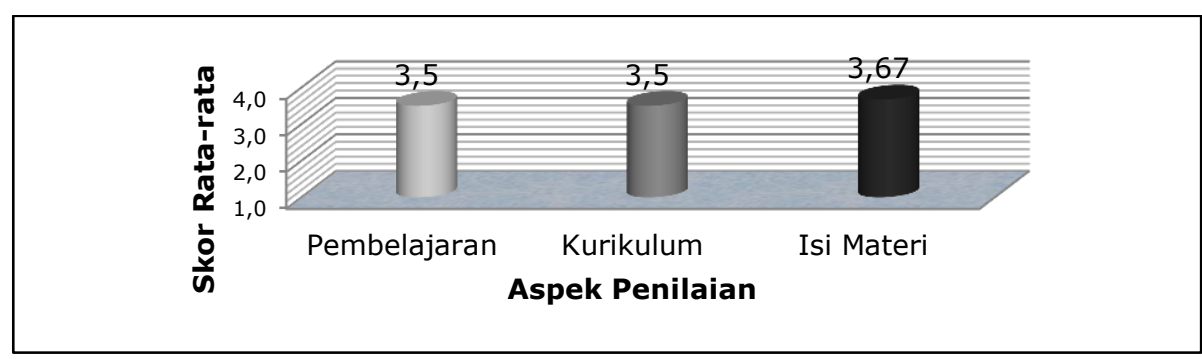

Gambar 1 Histogram Hasil Validasi Ahli Materi

Hasil review ahli media menunjukkan validitas multimedia pembelajaran interaktif memperoleh kualifikasi baik (lihat Gambar 2). Hasil ini artinya komposisi warna, teks, tampilan layar, perintah atau navigasi, dan desain program telah memenuhi standar layak untuk digunakan dalam pembelajaran. Revisi media tidak dilakukan karena tidak ada saran perbaikan.

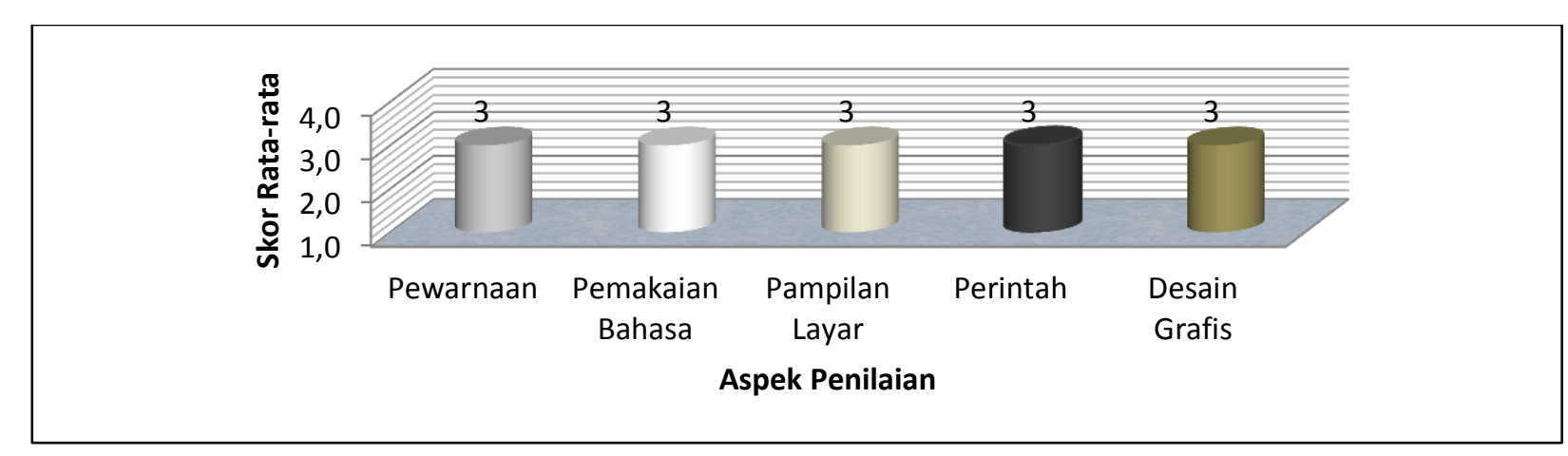

Gambar 2 Histogram Hasil Validasi Ahli Media

Hasil uji kelompok kecil menunjukkan validitas multimedia pembelajaran interaktif sangat baik (lihat Gambar 3). Hasil ini artinya, kualitas isi, kemenarikan, pembentukan karakter, evaluasi, tata bahasa, membangkitkan motivasi, dan ilustrasi sudah dianggap layak bila digunakan oleh siswa. Revisi media tidak dilakukan karena tidak ada saran perbaikan. 


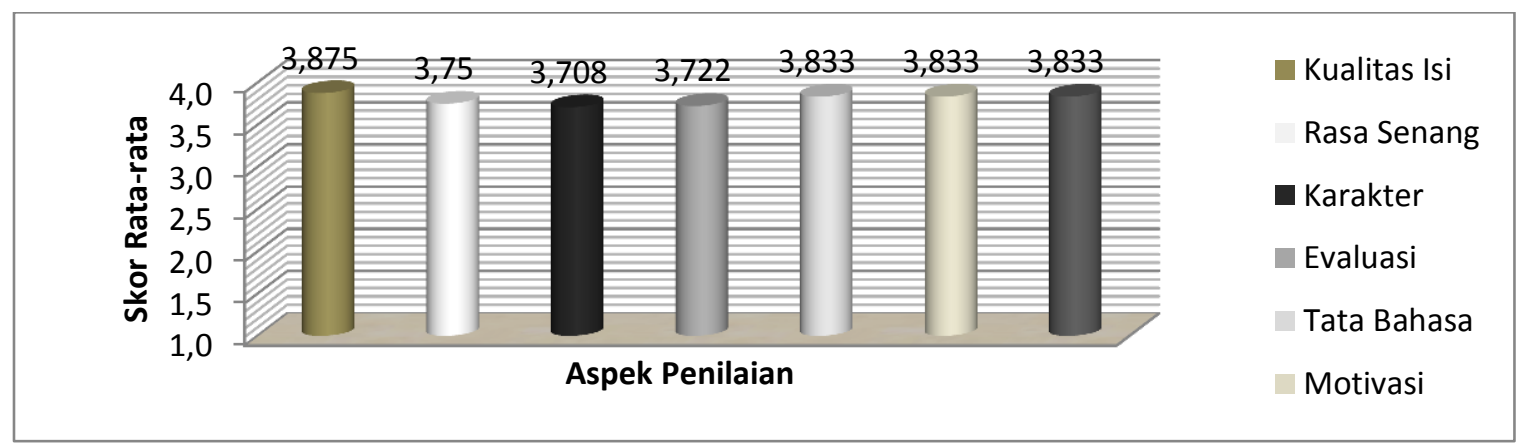

Gambar 3. Histogram Hasil Rata-rata tiap Aspek pada Uji coba Kelompok Kecil

\section{KESIMPULAN}

Berdasarkan hasil penelitian dan pembahasan, maka dapat diambil kesimpulan.

1) Telah dilakukan pengembangan bahan ajar yang menghasikan software multimedia interaktif materi Listrik Dinamis dengan materi yang ditampilkan secara berjenjang dan soal dalam uji kompetensi maupun evaluasi ditampilkan secara acak.

2) Kualitas kelayakan multimedia pembelajaran interaktif materi Listrik Dinamis diperoleh berdasarkan kriteria penilaian kelayakan pada tabel 4.7. Penilaian ahli materi pada aspek pembelajaran, Kurikulum, dan isi materi termasuk dalam kategori sangat baik. Penilaian ahli media pada aspek pewarnaan, pemakaian bahasa, tampilan pada layar, perintah, dan desain tampilan termasuk dalam kategori baik. Uji coba kelompok kecil dengan rata-rata keseluruhan aspek termasuk dalam kategori sangat baik. Uji coba kelompok besar menunjukan aspek kualitas isi, rasa senang, karakter, evaluasi, tata bahasa, motivasi dan aspek ilustrasi termasuk dalam kategori sangat baik.

\section{DAFTAR PUSTAKA}

[1] Borg, W. R. \& Gall M. D. (1983). Educational Research AnIntruction. fourth edition. New York: Longman

[2] Emzir. (2013). Metodologi Penelitian Pendidikan:Kuantitatif dan Kualitatif. Cetakan ke7. Jakarta: Raja Grafindo Persada.

[3] Puslitjaknov Departemen Pendidikan Nasional. (2008). Metode Penelitian Pengem bangan. Tersedia: http://www.infokursus.net/download/060409135 4Metode_Penel__Pengemb_Pembelajaran.pdf. Pada 18 Pebruari 2015. Jam 20.00 WITA

[4] Saifudin, A. (2012). Pengembangan Media Pembelajaran Berbasis Komputer Mata Pelajaran IPS SMP. Dalam Jurnal Falasifa. 1, (2), 63-86.

\section{Tersedia}

https://jurnalfalasifa.files.wordpress.com/2012/1 1/5-ahmad-saifudin-pengembangan-mediapembelajaran-berbasis-komputer-matapelajaran-ips-smp.pdf. Pada 18 Juni 2015. Jam 02.13 WITA 